\title{
PROGRESSION OF AUTOANTIBODIES ANTI-GAD AND ANTI-IA2 IN TYPE 1A DIABETICS AGED OF 5 TO 21 YEARS IN CÔTE D'IVOIRE
}

\author{
Aïssé Florence Judith Trébissou ${ }^{1,2}$, Chiayé Claire Antoinette Yapo-Crezoit ${ }^{3}$, Pascal \\ Sibailly $^{4}$, Mamadou Sanogo 5 , Amos Ankotché4, Dinard Kouassi², Marie Thérèse Kouassi², \\ Hatem Masmoudi ${ }^{6}$, Adou Francis Yapo' ${ }^{1}$.
}

1. Laboratory of Biochemistry-Pharmacodynamics, Faculty of Biosciences, Felix Houphouët Boigny University, Côte d'Ivoire, P.O BOX 582 Abidjan 22.

2. National Public Health Institute, Abidjan, Côte d'Ivoire, P.O. BOX 47 Abidjan.

3. Pole of Biology Immunity, Pasteur Institut of Côte d'Ivoire, P.O. BOX 490 Abidjan 01.

4. Diabetes Clinic, University Hospital Center (U.H.C) of Treichville, Côte d'Ivoire.

5. Diabetology and Endocrinology Department, University Hospital Center (U.H.C) of Yopougon.

6. Laboratory of Immunology, Hospital Habib Bourguiba of Sfax, 3029Sfax, Tunisia.

Corresponding author Dr. Aïssé Florence Judith Trébissou: aisse.judith@gmail.com, National Public Health Institute, Abidjan, Côte d'Ivoire, P.O. BOX 47 Abidjan 


\section{Abstract}

Background: Diabetes autoantibodies are indispensable markers of diabetes classification.

Objective: to research autoantibodies anti-GAD and anti-IA2 in type 1A diabetics (T1D) aged 5 to 21 years, and to follow the progression of these autoantibodies in T1D patients, in Côte d'Ivoire.

Methods: The study population composed of 28 T1D patients, aged 5 to 21 years. T1D were followed up in two diabetes care centers in Abidjan district, Endocrinology departments of U.H.C of Yopougon and Treichville. Anti-GAD and anti-IA2 autoantibodies were researched by ELISA.

Results: anti-GAD and anti-IA2 were present in T1D and their siblings. After 2 years of diabetes, the titer of the anti-GAD autoantibodies increased to the mean value of $677.10 \pm$ 353.20 IU / $\mathrm{ml}$. Then, a fall of the anti-GAD autoantibodies until the cancellation was observed from the 8 th to the 9 th with values of $117 \mathrm{IU} / \mathrm{ml}$ to $10.14 \mathrm{IU} / \mathrm{ml}$. Anti-IA2 autoantibodies fall at 9 th year of diabetes with a value of $55.10 \mathrm{IU} / \mathrm{ml}$.

Conclusion: anti-GAD and anti-IA2 autoantibodies persist after 9 years of diabetes, causing total destruction over time of the pancreatic $\beta$-cell mass in patients from Côte d'Ivoire, leading them to the death.

Key words: diabetes autoantibodies, type 1A diabetes, Côte d'Ivoire. 


\section{INTRODUCTION}

Type 1A diabetes is an autoimmune disease, the final consequence of a slow and gradual process of $\beta$-cell destruction of pancreatic islet Langerhans cells leading, in the absence of treatment, to ketoacidosis [1]. This destruction of the $\beta$ cells, responsible for the production of insulin, begins with the initiation of the autoimmune reaction triggered by certain environmental factors and, after several years of evolution, leads to the clinical signs of the disease when the mass of $\beta$ cells become insufficient to regulate blood glucose [2]. Type 1A diabetes or juvenile insulin-dependent diabetes is a major public health problem due to the often early onset of the disease, increasing incidence in most populations, lack of curative treatment and vascular complications related to residual hyperglycemia despite insulin injections in treated patients [3]. It is a disease that affects more than 31 million people worldwide [4], and 138,000 people aged 19 to 79 died of type 1A diabetes in 2011 [5]. In Africa, 39100 children aged 0-14 years have type $1 \mathrm{~A}$ diabetes in 2013 [5]. In Côte d'Ivoire, $0.4 \%$ of children and adolescents are type 1 diabetics (T1D) [6]. It is an incurable disease that is gaining momentum in Africa and particularly in Côte d'Ivoire. Today, the diagnosis of type 1A diabetes is biological (fasting glucose greater than $1.26 \mathrm{~g} / \mathrm{l}$ ) and requires the search for autoantibodies of diabetes as a confirmation marker for autoimmune process [7]. According to some authors, these autoantibodies diabetes disappear with the duration of diabetes [8]. In Côte d'Ivoire, diabetes autoantibodies screening tests are not performed leading to a lack of the diagnosis of type $1 \mathrm{~A}$ diabetes and a high rate of morbidity and early mortality in this type of Ivorian population. The search for autoantibodies is essential in the classification of diabetics, some of whom are taken as type 2 diabetics when they are actually type $1 \mathrm{~A}$. It is therefore important to diagnose diabetes as early as possible in order to avoid the rapid evolution of the disease and its aggravation in the long term. The aim of this work was to research diabetes autoantibodies in T1D aged 5 to 
21 years, and to follow the progression of these autoantibodies in T1D, in Côte d'Ivoire. This study was extracted from the Ph.D thesis written by Trébissou Aïssé Florence Judith.

\section{Material and Methods}

\subsection{Material}

\section{Study population}

The study population composed of 28 known T1D patients aged 5 to 21 years and followed up in the Endocrinology department of the University Hospital Center (U.H.C) of Yopougon and the Diabetes Clinic of U.H.C of Treichville, Abidjan, Côte d'Ivoire. The sex ratio was 0.86 (13 boys and 15 girls); and the mean age of T1D was $12.62 \pm 2.75$ years. This cross-sectional study started in January 2014 and ended in April 2016.

\section{Selection criteria}

\section{Inclusion criteria}

The T1D selected were aged from 5 to 21 years and declared diabetics between 2007 and 2016 . They had a complete medical folder of T1D.

\section{Non-inclusion criteria}

HIV-positive patients undergoing antiretroviral therapy were excluded from the study because of the impact of ARVs that would lead to hyperglycemia.

\section{Biological Material}

The biological material composed essentially of serum. These sera were obtained after centrifugation at $3000 \mathrm{rpm}$ for 3 minutes of venus blood collected on dry tubes in T1D and their siblings.

\subsection{Methods}


The project was approved by the ethics committee of Pasteur Institut of Côte d'Ivoire.

\subsubsection{Search of Anti-Glutamic Acid Decarboxylase Autoantibodies and anti-tyrosine Phosphatase IA2 Autoantibodies}

The dosage of these two autoantibodies is done by ELISA method with commercial kits anti-GAD ELISA (IgG) and anti-IA2 ELISA (IgG) (Euroimmun ${ }^{\circledR}$, Germany). The test is positive if the titer of anti-GAD and anti-IA2 autoantibodies is greater than or equal to $10 \mathrm{IU} / \mathrm{ml}$ [9].

\subsection{Statistical analysis}

Statistical analysis of the data was done with the GraphPad Prism.V5.01 software using the Student's test. The difference between two variances was significant if $\mathrm{p}<0.05$.

\subsection{Results}

Figure 1 shows the titer of anti-GAD autoantibodies according to the age of the disease in T1D. These results show that after one year of diabetes, the titer of anti-GAD autoantibodies was $63.30 \pm 37.70 \mathrm{IU} / \mathrm{ml}$. After 2 years of diabetes, the mean value of the anti-GAD autoantibodies raised to $677.10 \pm 353.20 \mathrm{IU} / \mathrm{ml}$ (Figure 3). After 5 to 6 years of diabetes, the results showed a fall in anti-GAD autoantibodies from $587.60 \pm 305.80 \mathrm{IU} / \mathrm{ml}$ to $247.40 \pm 210.70 \mathrm{IU} / \mathrm{ml}$. Then a rebound of anti-GAD autoantibodies was observed at the 7th year of diabetes with a value of $956.50 \pm 171.50 \mathrm{IU} / \mathrm{ml}$. Then, a fall of the anti-GAD autoantibodies until the cancellation was observed from the 8th to the 9th year with values of $117 \mathrm{IU} / \mathrm{ml}$ to $10.14 \mathrm{IU} /$ $\mathrm{ml}$ (Figure 1).

Figure 2 shows the titer of anti-IA2 autoantibodies according to the age of diabetes in T1D. These results show that after one year of diabetes, the titer of the anti-IA2 autoantibodies was at its maximum value of $321 \mathrm{IU} / \mathrm{ml}$. Then, a fall of the anti-IA2 autoantibodies from the 2nd year until the 7 th year was observed, with values varying from $248,60 \pm 95,40 \mathrm{IU} / \mathrm{ml}, 89,80 \pm$ 
$25,78 \mathrm{IU} / \mathrm{ml}, 49.95 \pm 39.05 \mathrm{IU} / \mathrm{ml}$ at $25.73 \mathrm{IU} / \mathrm{ml}$ (2nd, 5th, 6th and 7 th year of diabetes).

Subsequently, a slight increase in anti-IA2 autoantibodies was observed in the 9th year of diabetes with a value of $55.10 \mathrm{IU} / \mathrm{ml}$ (Figure 2).

\section{Discussion}

Type $1 \mathrm{~A}$ diabetes is an autoimmune disease due to the destruction of pancreatic islet $\beta$-cells by T cells. So, by a rupture of the peripheral tolerance of the immune system with respect to $\beta$ cells-self-antigens, a phenomenon of "molecular mimicry" occurs between a sequence of a viral protein and that of an auto-antigen of the $\beta$-cell of Langerhans islets of the endocrine pancreas. Another mechanism involved is the «bystander effect », ie infection of the $\beta$-cells by a virus with a particular tropism for the latter, followed by their lysis and the release of self-antigens susceptible to activate self-reactive $\mathrm{T}$ cells for these autoantigens [10]. Thereby, T1D with young diabetes (1 to 2 years) who have not developed at least one diabetes autoantibody would not be T1D. So, as some authors have shown, diabetes autoantibodies disappear with duration of diabetes, hence the disappearance in time of diabetes auto-antibodies in T1D in Côte d'Ivoire. This would be due to the destruction of $\beta$-cells [8]. It appears important to introduce in diabetes care in Côte d'Ivoire the search for autoantibodies of diabetes, for a better classification and diabetes care.

The results so showed that the mean value of anti-GAD autoantibodies after 2 years of diabetes was maximal in T1D $(677.10 \pm 353.20 \mathrm{IU} / \mathrm{ml})$. Then, from the 5 th to the 6 th year, it falled to reach $247.40 \pm 210.70 \mathrm{IU} / \mathrm{ml}$ after 6 years of diabetes, followed by a brutal fall between the 8th and 9 th year of diabetes $(117 \mathrm{IU} / \mathrm{ml}$ at $10.14 \mathrm{IU} / \mathrm{ml})$. With regard to anti-IA2 autoantibodies, the results showed a maximum value of $310 \mathrm{IU} / \mathrm{ml}$ in the first year of diabetes, followed by a brutal fall from the 2 nd year, 5 th, 6 th until the 7 th year $(248.60 \pm 95.40 \mathrm{IU} / \mathrm{ml}, 89.80 \pm 25.78$ $\mathrm{IU} / \mathrm{ml}, 49.95 \pm 39.05 \mathrm{IU} / \mathrm{ml}$ and $25.73 \mathrm{IU} / \mathrm{ml}$ ). These results show that $\beta$-cells of Langerhans islets of the endocrine pancreas of these T1D know undergo a fast destruction, which can lead 
to the death of these. The rebound of anti-GAD autoantibodies observed at the 7 th year of diabetes and at the 9th year for anti-IA2 is thought to be due to the persistence of the humoral immune response against the islet cells of the Langherans of the pancreas. Indeed, according to Wilmot-Roussel et al., 2010 [8] anti-GAD and anti-IA2 autoantibodies persit during the type 1A diabetes. The body of T1D has secreted more anti-GAD and anti-IA2 autoantibodies to destroy the remaining $\beta$ cell mass.

\section{Conclusion}

In conclusion, this study shows the important role that anti-GAD and anti-IA2 autoantibodies play in diabetes care. Indeed, anti-GAD and anti-IA2 autoantibodies persist after 9 years of diabetes. Anti-IA2 auto-antibodies would be more persistent than anti-GAD in T1D in Côte d'Ivoire. It appears essential to introduce the research of auto-antibodies anti-GAD and antiIA2 in diabetes care in Côte d'Ivoire, to allow better monitoring of diabetics.

\section{ACKNOWLEDGEMENTS}

We thank the Laboratory of Immunology, Hospital Habib Bourguiba of Sfax, 3029Sfax, Tunisia, for the financially supported and autoantibodies assay.

\section{AUTHOR CONTRIBUTIONS}

Conceptualization: Aïssé Florence Judith Trébissou, Adou Francis Yapo, Chiayé Claire Antoinette Yapo-Crezoit.

Data curation: Aïssé Florence Judith Trébissou

Formal analysis: Aïssé Florence Judith Trébissou, Adou Francis Yapo

Funding acquisition: Hatem Masmoudi 
Investigation: Aïssé Florence Judith Trébissou, Sibailly Pascal, Sanogo Mamadou, Ankotché Amos

Methodology: Aïssé Florence Judith Trébissou

Supervision: Kouassi Dinard, Kouassi Marie Thérèse

Writing - original draft: Aïssé Florence Judith Trébissou

Writing - review \& editing: Aïssé Florence Judith Trébissou, Adou Francis Yapo

\section{References}

1. Faideau B, Larger E, Lepault $\mathrm{F}$ et al. Role of beta-cells in type 1 diabetes pathogenesis. Diabetes, 2005 ; 54, S87-S96.

2. Carel, JC, Boitard C. Pathogénie du diabète de type 1. Option/Bio, Le cahier Scientifique, $1998 ; 218,9-11$.

3. Boitard C, Mallone R. Diabète de type 1: vers de nouveaux biomarqueurs. Médecinesciences flammarion/lavoisier - actualités néphrologiques, $2010 ; 31-41$.

4. Vieira A, Druelle N, Courtney M, et al. Reprogramming pancreatic cells to $\beta$ cells. Médecine Sciences, 2013 ; 29, 749-755.

5. IDF (International Diabetes Federation). 2013. Available at: http://www.idf.org/diabetesatlas.

6. Agbre-Yace M L, Oyenusi E E, Oduwole A O, et al. Prevalence of diabetes mellitus among children and adolescents in the district of Abidjan in Cote d'Ivoire: a population based study. J Diabetes Metab Disord, 2016 ; 15,38.

7. Delic-Sarac M, Mutevelic S, Karamehic J, et al. ELISA Test for Analyzing of Incidence of Type 1 Diabetes Autoantibodies (GAD and IA2) in Children and Adolescents. Acta Inform Med, 2016 ; 24, 61-65. 
8. Wilmot-Roussel H., Dubois-Laforgue D., Carette C., Caillat-Zucman S. , Boitard C. , Timsit J. Persistance à long terme des anticorps anti-GAD et anti-IA-2 au cours du diabète de type 1 (DT1). Diabetes \& amp; Metabolism, 2010; 36 (S1): A89.

9. Warncke K, Fröhlich-Reiterer E E, Thon A et al. Polyendocrinopathy in children, adolescents, and young adults with type 1 diabetes: a multicenter analysis of 28,671 patients from the German/Austrian DPV-Wiss database. Diabetes care, 2010 ; 33, 20102012.

10. Geenen V. Nouvelles approches du diagnostic et de la pathogénie du diabète de type 1 . Louvain médical, 2004, 123, 260-266. 


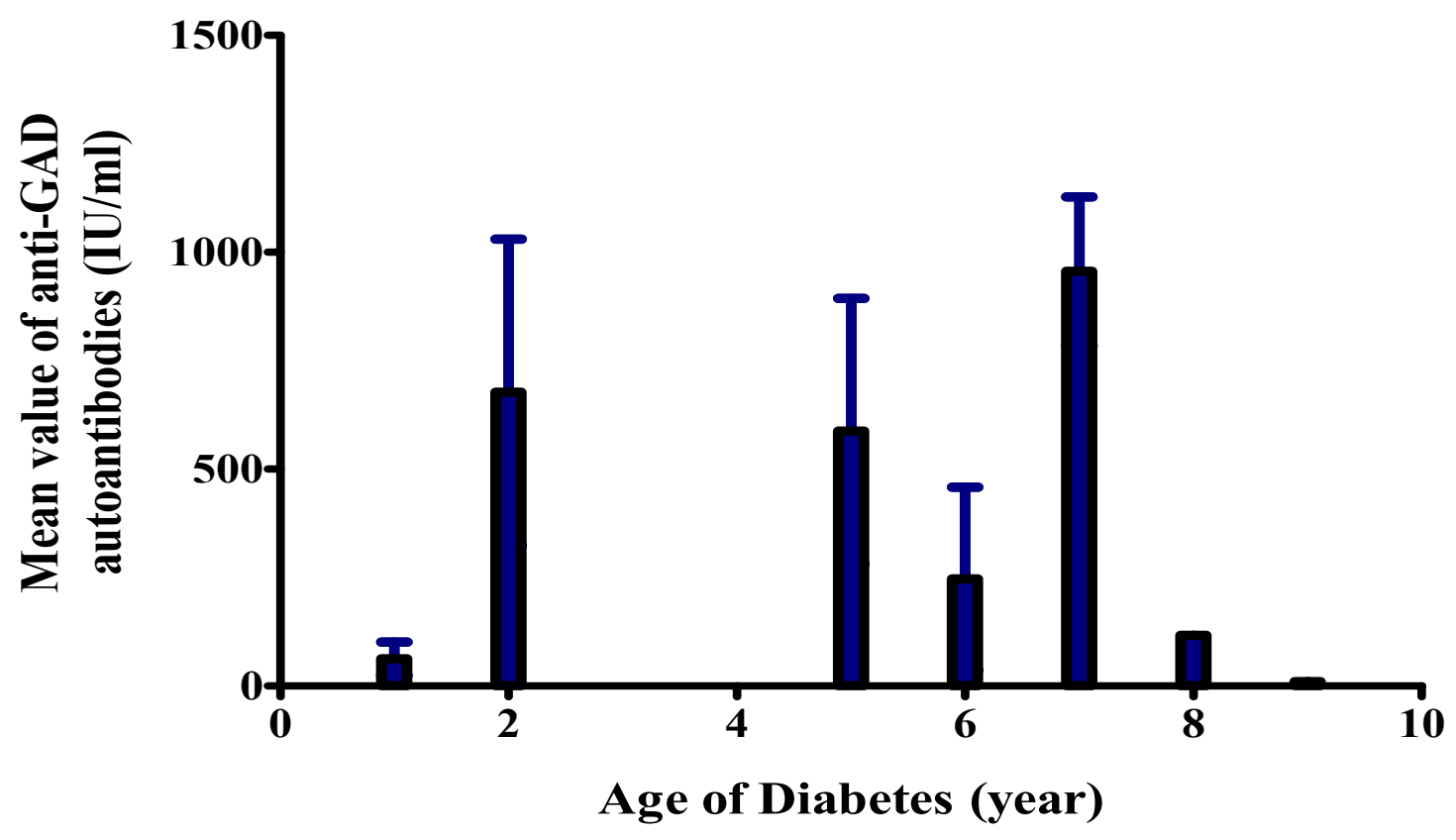

Figure 1: Mean value of Anti-GAD autoantibodies according to age of diabetes

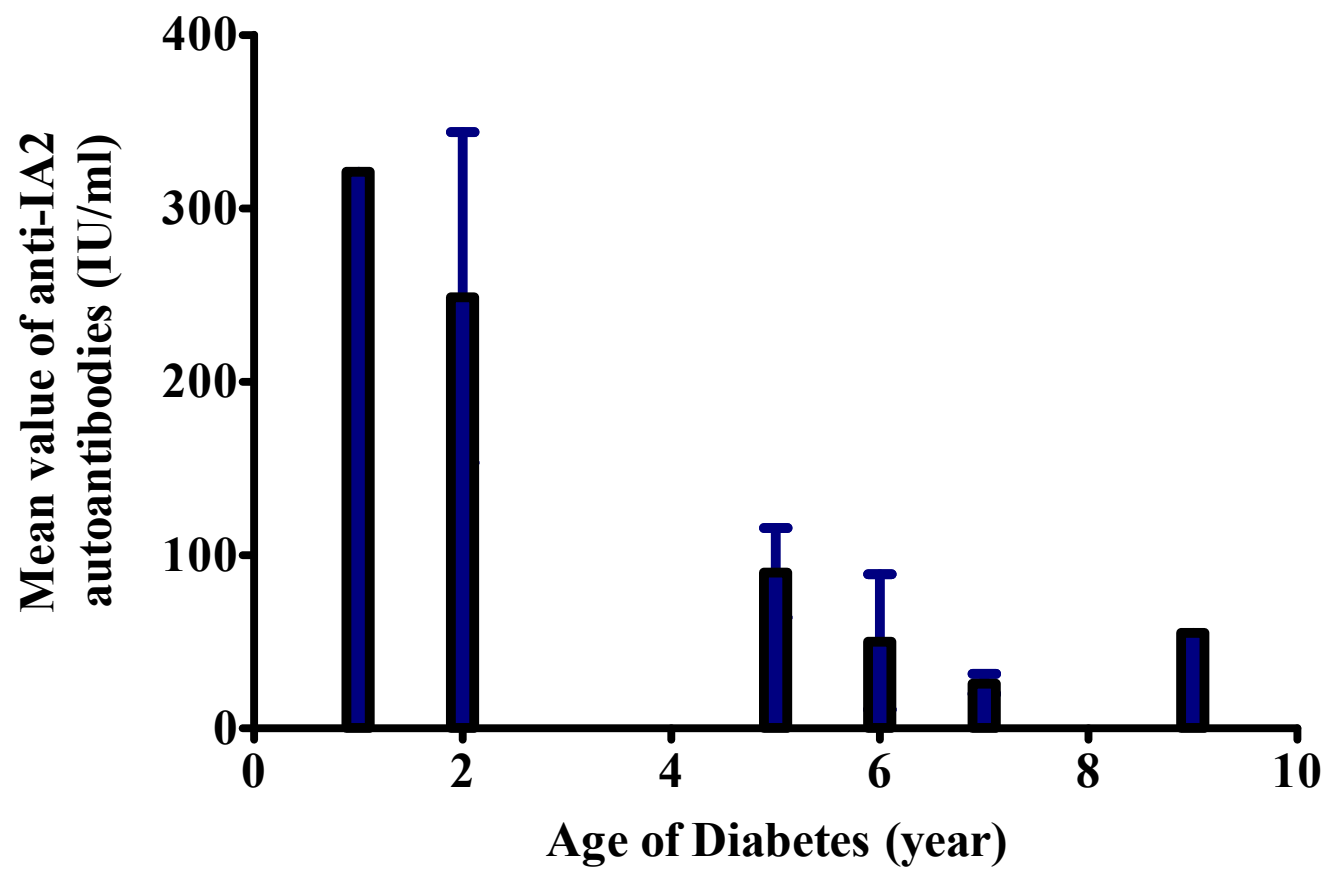

Figure 2: Mean value of Anti-IA2 auto-antibodies according to age of diabetes 